\title{
Clinical and Mycological Study of Scalp White Piedra in the State of Paraíba, Brazil
}

\author{
Zélia Braz Vieira da Silva Pontes/ ${ }^{+}$, Adriano Lira Ramos, Edeltrudes de Oliveira Lima*, \\ Maria de Fátima de Lacerda Guerra**, Neuza Maria Cavalcante Oliveira*, \\ Jozemar Pereira dos Santos***
}

\begin{abstract}
Laboratório de Micologia *Departamento de Ciências Farmacêuticas, Centro de Ciências da Saúde, Universidade Federal da Paraíba, Cidade Universitária, Castelo Branco III, 58038-910 João Pessoa, PB, Brasil **Secretaria de Saúde do Município, João Pessoa, PB, Brasil ***Departamento de Matemática e Estatística, Centro de Ciências e Tecnologia, Universidade Estadual da Paraíba, Campina Grande, PB, Brasil
\end{abstract}

White piedra is a superficial mycoses characterized by nodules on the hair shaft, caused by the basidiomycetous yeasts. In the present study, clinical and mycological findings of scalp white piedra caused by Trichosporon spp. are related. Twenty three cases of scalp white piedra were observed with a high incidence in women (87\%) and preschool children from 2 to $6(74 \%)$ years old. These groups presented a relationship of dependence with this infection. Despite the low socio-economic status, poor standards of hygiene, (48\% of the patients) as well as the fact that $30.4 \%$ of the children shared the same nursery, these factors were not significant for the transmission of the mycosis. These were the first reports of scalp white piedra in João Pessoa city, Paraíba, Brazil.

Key words: mycosis - scalp white piedra - Trichosporon spp. - Paraíba - Brazil

Piedra is a fungal infection of the hair shaft. Two varieties of piedra are recognized: black piedra caused by Piedraia hortai, and white piedra. Classically white piedra was considered to be produced by an asexual yeastlike fungus, Trichosporon beigelii (Rippon 1974). A taxonomic revision using molecular data has shown that the genus Trichosporon Behrend consists of six human pathogenic species: T. asahii, T. mucoides, T. ovoides, T. asteroides, T. cutaneum and T. inkin and all of which belong to the class Basidiomycetes (Guého et al. 1992). These species are considered causative agents of mucosa-associated, systemic mycosis, and superficial infections, including white piedra (Guého et al. 1994).

White piedra is characterized by the presence of irregular nodules along the hair shaft. The nodules are white or brown, of medium to soft consistency and their fungal elements which comprise artroconidia and/or blastoconidia can be easily detached from the hair shaft. White piedra is a cosmopolitan infection being found in the hair of the beard, moustache, genitals and axilla. Eyebrow and eyelash involvement can occur while on the scalp white piedra was described less frequently. It is described as being commonly associated with bacteria (Thérizol-Ferley et al. 1994). Direct microscopic examination of infected hair and culture enables a clear differential diagnosis to be made (Figueras \& Guarro 2000).

This study sought to investigate related cases of scalp white piedra among patients of both sexes and to deter-

${ }^{+}$Corresponding author. Fax: + 55-83-216.7094. E-mail: pesqces@ccs.ufpb.br

Received 8 October 2001

Accepted 25 April 2002 mine whether factors such as low socio-economic status, poor standards of hygiene and people living together would have any influence upon the transmission of this mycosis.

\section{MATERIALS AND METHODS}

The study included 23 patients with clinical presentation of piedra examined between 1998 to 2000. All these patients were from João Pessoa, a warm and humid region in the Northeast of Brazil. The patients were treated in the Dermatology clinic of the Lauro Wanderley Hospital Universitário, Universidade Federal da Paraíba and at the Secretaria de Saúde do Município. The mycological study was carried out at the Laboratório de Micologia of the Departamento de Ciências Farmacêuticas and included direct microscopic examination of hair samples on slides with $20 \%$ potassium hydroxide $(\mathrm{KOH})$ plus permanent black Quink ink (Parker) (2:1), and culture in Sabouraud dextrose agar (SDA, Difco Laboratories, Detroit) supplemented with choramphenicol $(200 \mu \mathrm{g} / \mathrm{ml})$. The cultures were incubated at room temperature $\left(28-30^{\circ} \mathrm{C}\right)$ up to four weeks. Trichosporon spp. were identified according to the criteria defined by Guého et al. (1992).

Statistical analyses were processed with the $\mathrm{SPSS}^{\circledR}$ (Norusis 1998) and statistical significance was determined by using Binomial Test analysis (Siegel 1975).

\section{RESULTS}

Mycological - Microscopic examination of hair samples presented consistent characteristics of white piedra and the nodules were compact masses made up of blastoconidia and arthroconidia (Fig. 1A).

Twenty-three strains which belong to the genus Trichosporon were culture positive. Macroscopically, with incubation on SDA for 10 days, colonies types were observed (Fig. 1B). Microscopic examination of slide cultures, on $2 \%$ malt extract agar, showed major structures 
such as pseudo mycelium and arthroconidia mycelium which eventually became barrel shaped and clavate blastoconidia and/or appressoria (Fig. 1C).

All strains produced urease (Christensen-urea medium), grew at $37^{\circ} \mathrm{C}$, did not ferment sugar and the capacity to assimilate carbohydrates was variable among some strains.

Association of Trichosporon spp. with bacteria was observed in 8 of the patients, but we could not ascertain whether they were coryneforms because of the difficult taxonomy of this group.

Clinical - The distribution of scalp white piedra in patients according to sex, age group, habitat and people who lived together is shown in the Table. Cases of white piedra in $87 \%$ of the females and $13 \%$ in the males were observed, with ages ranging from 2 to 42 years. In the 2-6 years age group at preschool age, the infection showed the highest frequency $(74 \%)$ with $88.2 \%$ of them being female. In the age group of people over 6 years old (26\%) only four patients were over 20 years old. A binomial test at the level of $5 \%$ of significance showed that the females and children from 2 to 6 years old were affected significantly with white piedra $(\mathrm{p}=0.000$ and $\mathrm{p}=0.035$, respectively).

Eleven $(48 \%)$ of the patients lived in the same slum. They presented low socio-economic status, poor standards of hygiene and 7 of them were children who attended the same nursery. Despite of the importance of the factors previously mentioned, they were not statistically significant for the transmission of these cases of white piedra with values of $p=1.000$ and $p=0.629$, respectively.

\section{DISCUSSION}

Although never reported previously in the State of Paraíba, a high incidence of scalp white piedra was ob- served in João Pessoa city, capital of the State. This infection in sub-tropical and mild climates has a low incidence, being more frequently registered in regions of tropical and mild climate. In Chile (Weinstein \& Alarcon 1953, Zaror \& Moreno 1996), Kuwait (Selim et al. 1988), India (Kamalam \& Thambiah 1981), Spain (Pereiro Miguens 1952), Israel (Gold et al. 1984) and Brazil (Godim-Gonçalves et al. 1991, Juang et al. 2000) there are some cases of scalp white piedra reported in the literature. The incidence of pubic white piedra (Carneiro et al. 1971, Benson et al. 1983, Torssander et al. 1985, Kalter et al. 1986, Stenderup et al. 1986, Avram et al. 1987, Fischman et al. 1989, Zaror et al. 1989, Waltzmam \& Leeming 1989, Almeida et al. 1990, Palungwachira et al. 1991, Thérizol-Ferley et al. 1994) is more frequently reported than on the scalp. Most of the reports of scalp white piedra demonstrated that it occurred among children and young adults (Kalamam \& Thambiah 1981, Gold et al. 1984, Selim et al. 1988, Zaror \& Moreno 1996) who were female (Kalamam \& Thambiah 1981, Gold et al. 1984, Selim et al. 1988). In Rio de Janeiro, Brazil, three cases of scalp white piedra in female children at preschool age were reported (Godim-Gonçalves et al. 1991) and more recently, in São Paulo, a single case was reported which happened to be in a 49 years old woman (Juang et al. 2000). In João Pessoa, the cases of scalp white piedra reported presented a relationship of dependence between females and children (2-6 years) of preschool age.

White piedra can be clinically indistinguishable from pediculosis, black piedra and trichobacteriosis including hair-shaft abnormalities such as moniletrix, trichorrhexis nodosa and trichoptilosis (Rippon 1974, Gold et al. 1984). In our study, 8 cases of scalp white piedra in association with bacteria were observed. Thérizol-Ferley et al. (1994) suggested that tricobacteriosis may play an important role

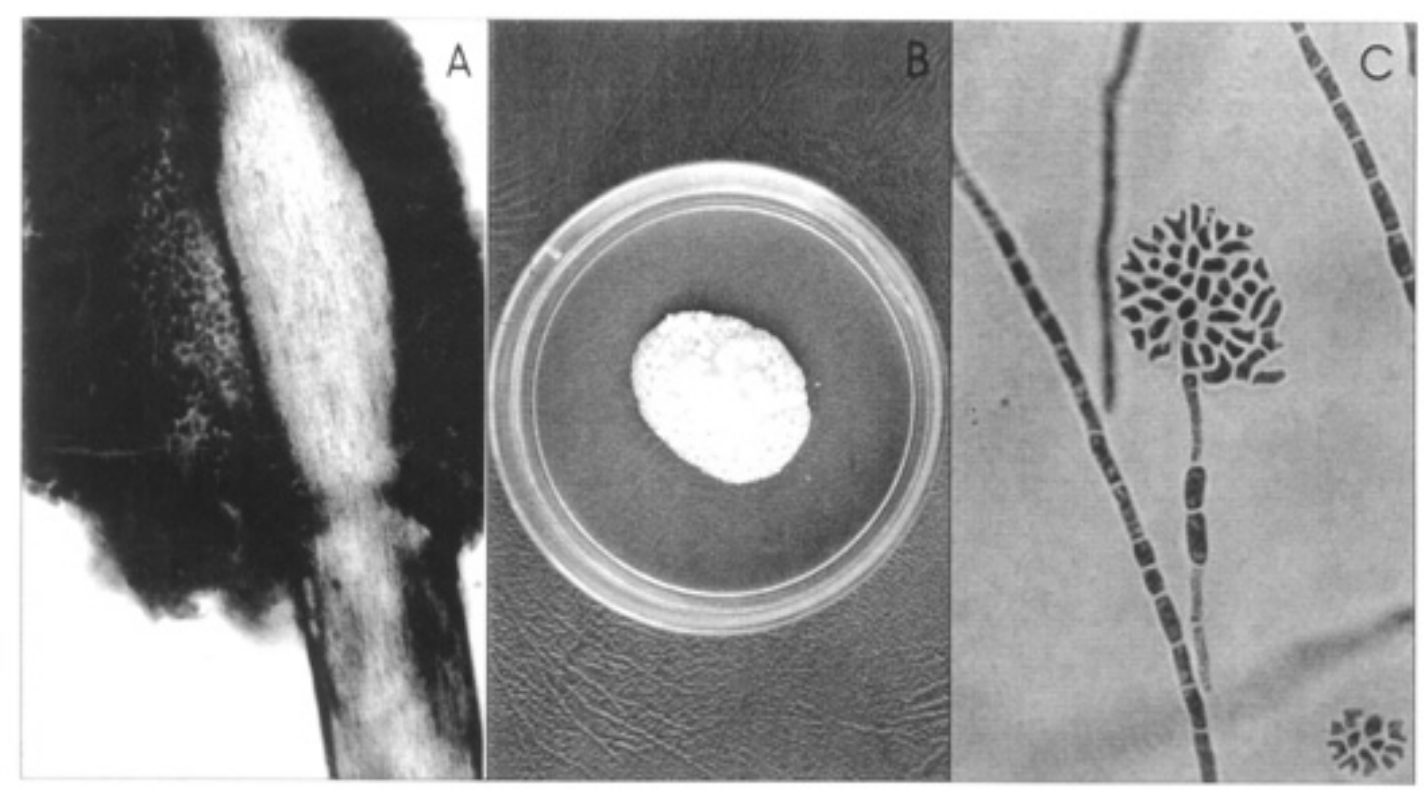

Fig. 1-A: piedric nodule involving hair shaft $(\mathrm{KOH}, \mathrm{x} 400)$; B: culture of Trichosporon spp. on Sabouraud dextrose agar; C: microscopic aspect: hyphae, arthroconidia and appressoria (x1000). 
TABLE

Distribuition of scalp white piedra by sex, age group, habitat and people who lived together

\begin{tabular}{lccc}
\hline & \multicolumn{2}{c}{ Age groups (years) } & Total \\
\cline { 2 - 3 } & $\begin{array}{c}2-6 \\
\mathrm{n}(\%)\end{array}$ & $\begin{array}{c}>6 \\
\mathrm{n}(\%)\end{array}$ & $\mathrm{n}(\%)$ \\
\hline Sex & & & \\
$\quad$ Female & $15(88.2)$ & $5(83.3)$ & $20(87)$ \\
Male & $2(11.8)$ & $1(16.7)$ & $3(13)$ \\
$\quad$ Total & $17(100)$ & $6(100)$ & $23(100)$ \\
Habitat & & & \\
$\quad$ Slum & $7(41.2)$ & $4(66.7)$ & $11(48)$ \\
$\quad$ Others & $10(58.8)$ & $2(33.3)$ & $12(52)$ \\
$\quad$ Total & $17(100)$ & $6(100)$ & $23(100)$ \\
Living together & & & \\
$\quad$ Nursery & $7(41.2)$ & - & $7(30.4)$ \\
$\quad$ Others & $10(58.8)$ & $6(100)$ & $16(69.6)$ \\
$\quad$ Total & $17(100)$ & $6(100)$ & $23(100)$ \\
\hline
\end{tabular}

Source: Laboratório de Micologia at Universidade Federal da Paraíba

in the genesis of genitopubic white piedra. They pointed out a relative high frequency $(11.8 \%)$ of both manifestations observed in 449 Gabonese female patients in Africa. However, Figueras and Guarro (2000) reported that bacteria were always observed at the periphery of the nodules of white piedra, which suggests that they are not primary invaders.

The mode of infection in man is not clear, but white piedra has been described in horses, monkeys, dogs and the causative agents have been isolated from soil, water and vegetal matter (Kaplan 1959, Guého et al. 1992, Sugita et al. 2000). Some authors believe that poor hygienic habits, such as bathing in stagnant water (Benson et al. 1983) may result in white piedra. However, this fact was not observed by Gold et al. (1984). Factors such as low socioeconomic conditions and poor standards of hygiene were not significant in our cases of white piedra. Selim et al. (1987) suggested humidity as a predisposing factor of scalp white piedra and sexual and familiar transmission are also suggested as predisposing factors, particularly in the cases of pubic white piedra (Torssander et al. 1985, Kalter et al. 1986, Walzman \& Leeming 1989, ThérizolFerley et al. 1994). Temperature and humidity in João Pessoa are relatively high and perhaps may have influenced the development of cases of scalp white piedra. However, the fact that $30.4 \%$ of our children shared the same nursery, was not a significant factor in the transmission of this mycosis.

Trichosporon spp. was isolated from cases of scalp white piedra, thus improving our knowledge of this mycosis in João Pessoa city.

\section{ACKNOWLEDGMENTS}

To dermatologists and staff of the Hospital Universitário Lauro Wanderley, Dermatology Clinic, for collaboration in assisting our patients and to Dr Luís Zaror from the University of Valdívia, Chile, for providing micrographs.

\section{REFERENCES}

Almeida HL, Rivitti EA, Jaeger RG 1990. White piedra: ultrastructure and a new micro-ecological aspect. Mycoses 33: 491-497.

Avram A, Buot G, Binet A, Garcia AM, Cesarini JP 1987. Étude clinique et mycologique concernant 11 cas de trichosporie noueuse (piedra blanche) génito-pubienne. An Dermatol Venereol 114: 819-827.

Benson PM, Lapins NA, Odom RB 1983. White piedra. Arch Dermatol 119: 602-604.

Carneiro JA, Assis FA, Filho JT 1971. Piedra branca genital. 40 casos. An Bras Dermatol 46: 265-269.

Figueras MJ, Guarro J 2000. Ultrastructural aspect of the keratinolytic activity of piedra. Rev Iberoam Micol 17: 136141.

Fischman O, Pires de Camargo Z, Meireles MCA 1989. Genital white piedra: an emerging fungal disease? 5th International Conference on Mycoses. PAHO Sci Publ 396: 70-76.

Gold I, Sommer B, Urson S, Schewach-Millet MA 1984. White piedra. A frequently misdiagnosed infection of hair. Int $J$ Dermatol 23: 621-623.

Gondim-Gonçalves H, Mapurunga ACP, Melo-Monteiro C, Lowy G, Lima AAB 1991. Piedra branca - Revisão de literatura a respeito de três casos. Rev Bras Med 48: 541547.

Guého E, Improvisi L, de Hoog GS, Dupont B 1994. Trichosporon on humans: a pratical account. Mycoses 37: 3-10.

Guého E, Smith MT, de Hoog GS, Billon-Grand G, Christen R, Batenburg-van der Vegte WH 1992. Contributions to a revision of the genus Trichosporon. Antonie van Leeuwenhoek 61: 289-316.

Juang JM, Marques ERMC, Couto LWM, Metelmann U, Silva EH 2000. Piedra branca no couro cabeludo. An Bras Dermatol 75 (Supl. 2): 25.

Kalter DC, Tschen JA, Cernoch PL, McBride ME, Sperber J, Bruce S, Wolf JE 1986. Genital white piedra: epidemiology, microbiology, and therapy. J Am Acad Dermatol 14: 982993.

Kamalam A, Thambiah AS 1981. Prevalence of dermatomycoses in Madras city. Indian J Med Res 73: 513-518.

Kaplan W 1959. Piedra in lower animals. A case report of white piedra in a monkey and a review of the literature. $J \mathrm{Am} \mathrm{Vet}$ Med Assoc 134: 113-117.

Norusis MJ 1998. SPSS Inc. SPSS for Windows - Base System User's Guide Release 9.0.

Palungwachira P, Chongsathien S, Palungwachira P 1991. White piedra. Australas J Dermatol 32: 75-79.

Pereiro Miguens M 1952. Piedra blanca europea (primer caso descrito en Espanã). Actas Derm Sif 43: 537-545.

Rippon JW 1974. Piedra. In JW Ripon, Medical Mycology: the Pathogenic Fungi and the Pathogenic Actinomycetes, Saunders, Philadelphia, p. 91-95.

Selim MM, Kubec K, Baghli NMAAl 1988. Trichosporosis of the hairs of the scalp in Kuwait. Mycoses 31: 198-200.

Siegel S 1975. Estatística não Paramétrica para Ciências do Comportamento, McGraw-Hill do Brasil Ltda, São Paulo, $350 \mathrm{pp}$.

Stenderup A, Schonheyder H, Ebbesen P, Melbye M 1986. White piedra and Trichosporon beigelii carriage in homosexual men. J Med Veter Mycol 24: 401-406.

Sugita T, Nishikawa A, Ichikawa T, Ikeda R, Shinoda T 2000. Isolation of Trichosporon asahii from environmental materials. Med Mycol 38: 27-30.

Thérizol-Ferly M, Kombila M, Gomez de Diaz M, Douchet C, Salaun Y, Barrabes A, Duong TH, Richard-Lenoble D 1994. White piedra and Trichosporon species in equatorial Af- 
750 Study of Scalp White Piedra • Zélia Braz Vieira da Silva Pontes et al.

rica. II. Clinical and mycological associations: an analysis of 449 superficial inguinal specimens. Mycoses 37: 255260.

Torssander J, Carlsson B, von Krogh G 1985. Trichosporon beigelii: increased ocurrence in homosexual men. Mykosen 28: 355-356.

Walzman M, Leeming JG 1989. White piedra and Trichosporon beigelii: the incidence in patients attending a clinic in geni- tourinary medicine. Genit Med 65: 331-334.

Weinstein M, Alarcon C 1953. Un caso de piedra. Rev Méd Chile 81: 52-53.

Zaror LC, Moreno MI 1996. White piedra. Report of one case. Rev Méd Chile 124: 593-596.

Zaror L, Fischman O, Petri V, Carvalho MTF, Pope S, Porfirio N 1989. Piedra blanca genital. Reporte de três casos. Bol Micol 4: 125-127. 